\title{
Parasitological monitoring of European bison in the Bieszczady Mountains
}

\author{
ALEKSANDER W. DEMIASZKIEWICZ, ANNA M. PYZIEL*, KATARZYNA FILIP-HUTSCH, \\ MACIEJ JANUSZCZAK**, WANDA OLECH ${ }^{* * *}$
}

\author{
W. Stefański Institute of Parasitology PAS, ul. Twarda 51-55, 00-818 Warszawa, Poland \\ *Department of Food Hygiene and Public Health Protection, Faculty of Veterinary Medicine, \\ Warsaw University of Life Sciences - SGGW, ul. Nowoursynowska 159, 02-776 Warszawa, Poland \\ ${ }^{* *}$ Carpathian Wildlife Research Station, Museum and Institute of Zoology PAS, \\ ul. Ogrodowa 10, 38-700 Ustrzyki Dolne, Poland \\ ***Department of Animal Genetics and Breeding, Faculty of Animal Sciences, \\ Warsaw University of Life Sciences - SGGW, ul. Ciszewskiego, 8, 02-787 Warszawa, Poland
}

\section{Demiaszkiewicz A. W., Pyziel A. M., Filip-Hutsch J., Januszczak M., Olech W. \\ Parasitological monitoring of European bison in the Bieszczady Mountains}

\section{Summary}

The aim of our study was to determine the level of parasitic infections in European bison (Bison bonasus) in the Bieszczady Mountains on the basis of coprological methods: flotation, decantation and the Baermann technique. 429 faecal samples were collected from European bison in the following Forest Districts: Baligród, Komańcza, Lutowiska, Stuposiany, Lesko and Cisna. Examination of faeces revealed the presence of eggs of gastrointestinal nematodes from the Trichostrongylidae family, as well as Nematodirus sp., Aonchotheca sp. and Trichuris sp., larvae of lung nematodes Dictyocaulus viviparus, eggs of tapeworms Moniezia sp. and oocysts of 7 species of coccidia, belonging to the genus Eimeria (E. bovis, E. zuernii, E. pellita, E. bukidnonensis, E. subspherica, E. ellipsoidalis and E. brasiliensis). The population of European bison in the Bieszczady Mountains turned out to be the only free-living herd not infected with the liver fluke Fasciola hepatica. The level of parasitic infections, observed during present study, was low and did not indicate clinical signs of parasitic disease, thus it did not require deworming.

Keywords: parasites, European bison, Bieszczady Mountains, coprological examinations

The European bison (Bison bonasus) is the largest mammal in Europe. Restitution of the European bison population was carried out in the Białowieża Primeval Forest by several generations of biologists, veterinary surgeons, foresters and scientists. In 1963, the first five animals (four cows and one bull) of the Lowland-Caucasian line were brought to the Bieszczady Mountains from enclosures in Pszczyna and Niepołomice. All individuals, placed in a quarantine enclosure in the forest district Stuposiany, were released into the natural environment in 1964. Since that time, the population of European bison increased and reached 550 individuals in 2018 (18).

Parasitic infections are one of the most important factors affecting health and the condition of wild ruminants, including European bison. Gastrointestinal nematodes, lung nematodes and liver flukes should be considered as the most common and pathogenic parasites of European bison (3).

Parasitofauna of European bison as well as prevalence and intensity of parasitic infections were well described in Białowieża Primeval Forest, where parasitological studies have been conducted for 100 years $(5,7,8,11-13,21)$. Parasitological monitoring was also performed in the Knyszyńska and Borecka Forest, inhabited by free-living wisent populations $(4,6)$.

The last studies of parasites of European bison in the Bieszczady Mountains have been performed in the years 1997-2000 and concerned the examination of few abomasa $(9,10)$. However, no current data about parasitological monitoring of animals from this area is available. The aim of our study was to determine the current level of parasitic infections in European bison in the Bieszczady Mountains on the basis of long-term examination of faecal samples. 


\section{Material and methods}

In years 2014 and 2018, a total of 429 bison faecal samples were collected in the Baligród, Komańcza, Lutowiska, Stuposiany, Lesko and Cisna Forest Districts. Samples were collected during two seasons: spring (April-May) and autumn (October-November). 206 samples were collected in 2014 (109 in spring and 97 in autumn) and 223 in 2018 (94 in spring and 223 in autumn).

Faeces were examined for the presence of eggs of gastrointestinal nematodes and oocysts of coccidia by the method of flotation in the sucrose solution. Eggs of flukes and larvae of lung nematodes were detected by the method of decantation and the Baermann technique respectively (14). Eggs, oocysts and larvae were identified on the basis of morphometrical features under the light microscope JENAVAL at a 100-400 × magnification $(14,15)$. Intensity of infection was estimated on the basis of faecal egg count in 3 grams of the examined sample.

\section{Results and discussion}

Examination of faecal samples of European bison in the Bieszczady Mountains revealed the presence of eggs of gastrointestinal nematodes from the Trichostrongylidae family, nematodes from the genus Aonchotheca, Nematodirus and Trichuris, tapeworms from the genus Moniezia, larvae of lung nematodes Dictyocaulus viviparus, as well as oocysts of 7 species of coccidia from the genus Eimeria. No eggs of liver fluke Fasciola hepatica were detected. The most prevalent were eggs of Trichostrongylidae family, present in over $90 \%$ of samples. Mean intensity of infection, observed in the present study, was low, not exceeding 223. In 2014, European bison was infected with 3 species of coccidia: E. bovis, E. zuernii and E. pellita, while in 2018 another 4 species were detected: E. bukidnonensis, E. subspherica, E. ellipsoidalis and E. brasiliensis. The most prevalent were oocyst of $E$. bovis, more intensively excreted during autumn.

Detailed results are presented in Table 1 and 2.

Anathomopathological studies of European bison in the Bieszczady Mountains
Tab. 1. Parasitic infections of European bison in the Bieszczady Mountains in 2014

\begin{tabular}{|l|c|c|c|c|c|c|}
\hline \multirow{2}{*}{ Parasite } & \multicolumn{3}{|c|}{ Spring (n=109) } & \multicolumn{3}{c|}{ Autumn (n=97) } \\
& Prevalence (\%) & \multicolumn{2}{|c|}{ Intensity } & Prevalence (\%) & \multicolumn{2}{c|}{ Intensity } \\
& & Range & Mean & & & Mean \\
\hline Trichostrongylidae & 93.5 & $1-299$ & 39.5 & 88.6 & $1-406$ & 44.7 \\
Aonchotheca sp. & 3.6 & $1-3$ & 1.7 & 4.1 & $1-6$ & 2.7 \\
\hline Nematodiurus sp. & 2.7 & $1-2$ & 1.3 & - & - & - \\
Trichuris sp. & 7.3 & $1-167$ & 38.2 & 3 & $15-30$ & 22.6 \\
\hline Eimeria bovis & 30.2 & $1-595$ & 72 & 11.3 & $1-908$ & 223 \\
\hline E. pellita & 1.8 & $0-2$ & 2 & 1 & 2 & 2 \\
\hline E. zuernii & - & - & - & 1 & 1 & 1 \\
Moniezia sp. & - & - & - & 2 & $1-18$ & 9.5 \\
\hline
\end{tabular}

Tab. 2. Parasitic infections of European bison in the Bieszczady Mountains in 2018

\begin{tabular}{|c|c|c|c|c|c|c|}
\hline \multirow{3}{*}{ Parasite } & \multicolumn{3}{|c|}{ Spring $n=94$} & \multicolumn{3}{|c|}{ Autumn $n=129$} \\
\hline & \multirow{2}{*}{ Prevalence (\%) } & \multicolumn{2}{|c|}{ Intensity } & \multirow{2}{*}{ Prevalence (\%) } & \multicolumn{2}{|c|}{ Intensity } \\
\hline & & Range & Mean & & Range & Mean \\
\hline Trichostrongylidae & 100 & $3-370$ & 61.9 & 97.6 & $1-155$ & 22.9 \\
\hline Aonchotheca sp. & 5.1 & $1-5$ & 3 & 2.3 & $1-2$ & 2.5 \\
\hline Nematodiurus sp. & 10.6 & $1-23$ & 7.6 & 0.7 & $0-1$ & 1 \\
\hline Trichuris sp. & 3.1 & $1-36$ & 5.3 & - & - & - \\
\hline Eimeria bovis & 19.1 & $1-81$ & 9.7 & 48.8 & $1-406$ & 21.7 \\
\hline E. pellita & 2.1 & $1-10$ & 5.5 & 0.7 & 6 & 6 \\
\hline E. zuernii & 3.1 & $2-4$ & 3 & 5.4 & $1-2$ & 1.2 \\
\hline E. bukidnonensis & 2.1 & $5-9$ & 7 & 6.2 & $1-23$ & 5 \\
\hline E. subspherica & 3.1 & $2-3$ & 2.3 & - & - & - \\
\hline E. ellipsoidalis & 3.1 & $1-7$ & 4.3 & 2.3 & $1-2$ & 1.6 \\
\hline E. brasiliensis & - & - & - & 0.7 & 5 & 5 \\
\hline Dictyocaulus viviparus & 31,9 & $1-35$ & 5,2 & 8,5 & $1-6$ & 2 \\
\hline Moniezia sp. & 3,1 & $1-9$ & 5 & - & - & - \\
\hline
\end{tabular}

performed in years 1997-2000 revealed infection with 12 species of gastrointestinal nematodes: Ostertagia ostertagi, O. lyrata, O. leptospicularis, O. kolchida, Spiculopteragia boehmi, Trichostrongylus axei, T. vitrinus, T. capricola, Cooperia surnabada, C. pectinata, Ashworthius sidemi and Aonchotheca bilobata. Nematodes Onchocerca lienalis were isolated from the gastrosplenic ligament of 3 European bison. One animal was also infected with liver fluke $F$. hepatica. Examination of 17 faecal samples revealed the presence of eggs of nematodes from the Trichostrongylidae family, oocysts of Eimeria sp. as well as single eggs of $F$. hepatica $(9,10)$.

Infection with lung nematodes was not registered during studies in 1997 nor in the years 2011-2014 (10). The landform of the Bieszczady Mountains and low humidity may affect the reduced survival of larvae of lung nematodes in the environment. Few larvae of D. viviparus were detected for the first time in that area in the faeces of European bison in the years 2015-2017 (Demiaszkiewicz A. pers. commun.). In the last year, the prevalence of this nematode reached $33.1 \%$, 
which might be a result of the growing population of European bison in the Bieszczady Mountains (16, 18). The percentage of European bison infestation with $D$. viviparus in the Białowieża Primeval Forest reached a similar level (12-32.6\%) whereas in the Borecka Forest it was twice as high (62-72\%). In the Knyszyńska Forest, the infection with lung nematodes in European bison has not been diagnosed so far (6).

In the present study no eggs of liver fluke $F$. hepatica were found. In 1997, mature flukes were isolated from the liver of one bison and eggs of the fluke were found also in one faecal sample (10). Since that time, no $F$. hepatica were found in wisent. Occurrence of this trematode in the environment strictly depends on the presence of the intermediate host, the water snail Galba truncatula, which inhabits mostly lower pastures of the Bieszczady Mountains $(1,2,19)$. However, European bison spend vegetation season in higher parts of the Mountains, not inhabited by Galba truncatula. Animals return to lower pastures together with first snow and stay there during winter, when there are no invasive forms of $F$. hepatica in the environment $(16,20)$.

However, free-living European bison from NorthEastern Poland are highly infected with $F$. hepatica. The trematode is the most prevalent in the Białowieża Primeval Forest (70-80\%), less prevalent in Borecka Forest (36-83.8\%) and the least in Knyszyńska forest (37-57\%) (6).

Most parasites, observed during present studies, were more prevalent in the spring than autumn. For gastrointestinal nematodes from the family Trichostrongylidae, it may be associated with spring rise: the development of larvae in abomasal mucosa after winter and hence increased excretion of parasites eggs to the environment during spring (3). Isolation of 4040 IV stage larvae of Ostertagiinae nematodes from abomasal mucosa of one wisent and only 12 adult nematodes inside the abomasum confirm the scale of this phenomenon (10). Prevalence of Trichostrongylidae nematodes in European bison was similar to those observed in the Białowieża Primeval Forest as well as Knyszyńska and Borecka Forest, reaching from $88.6 \%$ to $100 \%$. Prevalence of nematodes from the genus Aonchotheca in the Bieszczady Mountains was much lower, not exceeding a few percent while it reached $15 \%$ in the Knyszyńska Forest, $46.5 \%$ in the Białowieża Primeval Forest and over $53 \%$ in the Borecka Forest. Aonchotheca bilobata is a common parasite in India and Vietnam. European bison probably assimilated the nematode while staying in zoological gardens (5).

Nematodes from the genus Nematodirus were found in $0.7-10.6 \%$ of examined samples in the Bieszczady Mountains. Prevalence of the nematode in European bison in Białowieża Primeval Forest was similar, reaching $0.5-4 \%$ whereas in Borecka Forest it was much higher and estimated at 9-28\%. Nematodirus sp. was not found in animals in the Knyszyńska Forest.
The level of European bison infection with nematodes from the genus Trichuris and tapeworms from the genus Moniezia was similar to these observed in NorthEastern Poland. In the Borecka Forest, wisents were infected with flukes Paramphistomum cervi (1.6-3\%) an animals from the Knyszyńska Forest were infected with nematodes Strongyloides sp. (16.4\%) whereas none of these parasites was found in the Bieszczady Mountains (6).

Seven species of coccidia from the genus Eimeria were detected in European bison in the present study. Previous studies from North-Eastern Poland revealed the presence of 8 species in the Białowieża Primeval Forest and 6 in Knyszyńska and Borecka Forest. The most common species in all wisent populations was E. bovis, present in 11.3-48.8\% of examined samples in the Bieszczady Mountains, $73-85 \%$ in the Białowieża Primeval Forest, $27-64.5 \%$ in Borecka Forest and $13.9-31 \%$ in the Knyszyńska Forest. Other species of coccidia were only a few percent prevalent, infecting animals with a low intensity. The prevalence of coccidian infection was higher only in the Białowieża Primeval Forest and reached $21 \%$ for E. zuernii, $16.6 \%$ for E. ellipsoidalis and 12\% for E. pellita (6).

The level of parasitic infections in European bison in the Bieszczady Mountains is similar to animals inhabiting North-Eastern Poland. In the present study, eggs of gastrointestinal nematodes from the genus Nematodirus and Trichuris, larvae of lung nematodes $D$. viviparus, eggs of tapeworms from the genus Moniezia and oocysts of 7 species of coccidia were registered for the first time in European bison in the Bieszczady Mountains. Population of European bison in this area is the only one not infected with $F$. hepatica. However, the latest detection of lung nematodes $D$. viviparus in wisents in the Bieszczady Mountains is disturbing and demands regular monitoring. The level of parasitic infections of the examined population of European bison did not indicate clinical signs of parasitic disease and did not require deworming so far.

\section{References}

1. Chowaniec W., Dróżdż J.: Badania nad biologią i ekologią błotniarki moczarowej (Galba truncatula) oraz form larwalnych motylicy wątrobowej Fasciola hepatica. Wiad. Parazytol. 1959, 4, 433-435.

2. Chowaniec W., Dróżdż J.: Badania nad biologią i ekologią Galba truncatula oraz nad formami larwalnymi Fasciola hepatica. Acta Parasit. Pol. 2013, 7, 143-160.

3. Demiaszkiewicz A. W.: Helminty i wywoływane przez nie helmintozy dzikich przeżuwaczy. Kosmos 2005, 54, 61-71.

4.Demiaszkiewicz A. W., Bielecki W., Rodo A., Pyziel A. M.: Parazytofauna żubrów w Puszczy Boreckiej. Med. Weter. 2018, 74, 253-256.

5. Demiaszkiewicz A. W., Pyziel A. M.: Kształtowanie się helmintofauny żubrów w Puszczy Białowieskiej, [w:] Kowalczyk R., Ławreszuk D., Wójcik J. M. (red.): Ochrona żubra w Puszczy Białowieskiej. Zagrożenia i perspektywy rozwoju. Białowieża 2010, s. 224.

6. Demiaszkiewicz A. W., Pyziel A. M., Kuligowska I., Lachowicz J.: Monitoring zarażenia żubrów pasożytami w trzech puszczach północno-wschodniej Polski (Białowieskiej, Boreckiej i Knyszyńskiej) w latach 2011-2013. Europ. Bison Conserv. News 2014, 7, 35-42. 
7.Demiaszkiewicz A. W., Pyziel A. M., Lachowicz J.: Stan zarażenia żubrów w Puszczy Białowieskiej helmintami w sezonie zimowym 2007/2008. Europ. Bison Conserv. News 2008, 1, 42-53.

8. Dróżdż J.: A study on helminths and helminthiases in bison, Bison bonasus (L.) in Poland. Acta Parasit. Pol. 1961, 9, 55-95.

9. Dróżdż J., Demiaszkiewicz A. W., Lachowicz J.: Exchange of gastrointestinal nematodes between roe deer and red deer (Cervidae) and European bison (Bovidae) in the Bieszczady Mountains (Carpathians, Poland). Acta Parasitol. 2002, 314-317.

10. Dróżdż J., Demiaszkiewicz A. W., Lachowicz J.: Helmintofauna żubrów Bison bonasus (L.) żyjących na swobodzie w Bieszczadach (Karpaty, Polska). Wiad. Parazytol. 2000, 46, 55-61.

11.Dróżḋ̇ J., Demiaszkiewicz A. W., Lachowicz J.: Kształtowanie sie fauny nicieni żołądkowo-jelitowych wolno żyjących żubrów w Puszczy Białowieskiej w ciągu ostatnich 17 lat (1984-2001). Wiad. Parazytol. 2002, 48, 375-381.

12. Dróżḋ J., Demiaszkiewicz A. W., Lachowicz J.: The helminth fauna of freeranging European bison, Bison bonasus (L.). Acta Parasit. Pol. 1989, 34 117-124.

13. Dróżdż J., Demiaszkiewicz A. W., Lachowicz J.: The helminth fauna of freeranging European bison, Bison bonasus (L.), studiem again 8 years after reduction of Bison, in the Białowieża Forest. Acta Parasit. 1994, 39, 88-91.
14. Pyziel A. M., Demiaszkiewicz A. W.: Coccidia (Apicomplexa: Eimeriidae) of the lowland European bison (Bison bonasus bonasus L.) in Poland. Vet. Parasitol. 2014, 202, 138-144.

15. Taylor M. A., Coop R. L., Wall R. L.: Veterinary Parasitology $3^{\text {rd }}$ edn Blackwell Publishing, Oxford, UK 2007, s. 874

16. Perzanowski K.: Historia, stan obecny i perspektywy ochrony populacji żubra w Bieszczadach. Roczn. Bieszczad. 2014, 22, 117-127.

17. Perzanowski K., Marszałek E.: Powrót żubra w Karpaty. The return of the wisent to the Carpathians. RDLP, Krosno 2012, s. 256.

18. Raczyński J.: Księga rodowodowa żubrów 2018. Białowieski Park Narodowy, Białowieża 2019, s. 82.

19. Stefański W. Dróżdż J.: Występowanie błotniarki moczarowej (Galba truncatula O. F. Müller) w Polsce. Wiad. Parazytol. 1958, 4, 431-432.

20. Wołoszyn-Gatęza A., Perzanowski K., Januszczak M., Pagacz S.: Habitat preferences of a European bison (Bison bonasus) population in the Carpathian Mountains. Ann. Zool. Fenn. 2016, 53, 1-18.

21. Wróblewski K.: Żubr Puszczy Białowieskiej. Wydawnictwo Polskie, Poznań 1927 , s. 125

Corresponding author: Prof. dr hab. Aleksander W. Demiaszkiewicz, ul. Twarda 51/55, 00-818 Warszawa; e-mail: aldem@twarda.pan.pl 